Ilmenau University of Technology

Institute of Economics

Ilmenau Economics Discussion Papers, Vol. 25, No. 128

How Does Online Streaming Affect Antitrust Remedies to Centralized Marketing? The Case of European Football Broadcasting Rights

Oliver Budzinski, Sophia Gaenssle \& Philipp KunzKaltenhäuser

July 2019

Institute of Economics

Ehrenbergstraße 29

Ernst-Abbe-Zentrum

D-98 684 Ilmenau

Phone 03677/69-4030/-4032

Fax 03677/69-4203 


\title{
How Does Online Streaming Affect Antitrust Remedies to Centralized Marketing? \\ The Case of European Football Broadcasting Rights
}

\author{
Oliver Budzinski, Sophia Gaenssle \& Philipp Kunz-Kaltenhäuser
}

\begin{abstract}
The collective sale of football broadcasting rights constitutes a cartel, which, in the European Union, is only allowed if it complies with a number of conditions and obligations, inter alia, partial unbundling and the no-single-buyer rule. These regulations were defined with traditional TV-markets in mind. However, the landscape of audiovisual broadcasting is quickly changing with online streaming services gaining popularity and relevance. This also alters the effects of the conditions and obligations for the centralized marketing arrangements. Partial unbundling may lead to increasing instead of decreasing prices for consumers. Moreover, the combination of partial unbundling and the no-single-buyer rule forces consumers into multiple subscriptions to several streaming services, which increases transaction costs. Consequently, competition authorities need to rethink the conditions and obligations they impose on centralized marketing arrangements in football. We recommend restricting the exclusivity of (live-)broadcasting rights and mandate third-party access to program guide information to redesign the remedies.
\end{abstract}

Keywords: collective sale of broadcasting rights, sports economics, antitrust, competition policy, centralized marketing, sports and media, football, online media

JEL-Codes: Z20, Z21, Z28, K21, L40, L83, L82

\footnotetext{
All authors: Institute of Economics, Ilmenau University of Technology, Ehrenbergstr. 29, Pf 1005 65, D-98693 Ilmenau, Germany. Corresponding author: Oliver Budzinski, Email: oliver.budzinski@tu-ilmenau.de. A revised version of the paper will be published in the International Journal of Sport Finance.
} 


\section{Introduction}

The ongoing process of digitization and the accompanying rise of online media challenge the traditional concepts and instruments of competition policy, fueling a discussion about necessary changes in antitrust rules and policies (inter alia, Budzinski \& Stöhr, 2018, with further references). So far, markets for search services, communication networks, online advertising, or e-commerce received most of the attention of competition authorities as well as of researchers, whereas competition policy debates on sports markets still center around more traditional, "offline" problems (see for a recent overview: Budzinski, 2019). However, the viewing behavior of "couch potato" sports fans is changing along with the rest of the population as well, more and more embracing new and social media (see section 3). With respect to antitrust issues in sports markets, these changes in the consumption behavior of sports fans particularly affect the marketing of sports broadcasting rights. While popular with sports associations and participating teams, the economic view of centralized systems of the sale of broadcasting rights has always been rather critical with respect to consumer welfare effects (see section 2) - in Europe especially regarding European-style football ${ }^{1}$ broadcasting. European competition authorities - both on the EU-level and on the member state-level - have consequently viewed such systems to constitute a cartel. However, the authorities also evaluated the consumer benefits of the institutional arrangements to outweigh its disadvantages - albeit only if a considerable number of obligatory remedies are respected by the football associations selling the broadcasting rights (see section 2). These remedies include the obligation to partial unbundling as well as so-called no-single buyer rule, demanding the seller to create several packages (or bundles) of broadcasting rights instead of auctioning only one comprehensive bundle. In doing so, competition on the level of broadcasting services shall be protected at the benefit of the consumers (i.e. the sports fans).

While the remedies appear to have been working well with football broadcasting consumers in the past, the shift of broadcasting from traditional free-television towards paid-for online streaming services considerably changes the consumer wel-

\footnotetext{
In this paper, the term football always denotes European-style football in contrast to, for in-
} stance, American Football. 
fare effects of the remedies, leading to negative reactions of football fans. This paper analyses from a competition- and sports-economic perspective why and how the effects of the current remedies justifying the allowance of the cartel centralized marketing of football broadcasting rights in the EU are changing in the light of the new media world. Our analysis shows how competition policy instruments (here: remedies to a cartel) that used to serve consumer welfare in the traditional media world now turn to harming consumer welfare in the new media world. Consequently, competition authorities need to rethink their conditional approval of joint selling arrangements of football broadcasting rights. We recommend focusing on restricting the exclusivity of (live-) broadcasting rights and demand third-party access to program guide information in order to redesign the remedies to centralized marketing arrangements in football.

The paper is organized as follows. Section 2 summarizes the economic discussion of centralized systems of selling broadcasting rights as well as the landmark European antitrust decisions in this regard. Section 3 reports selected developments in sports broadcasting and viewing behaviors, taking the example of Germany. Subsequently, we discuss the changing welfare effects of the traditional remedies in the light of the new media world (section 4), before drawing antitrust implications (section 5).

\section{Centralized Marketing of Broadcasting Rights - A Controversial Issue}

When it comes to commercially marketing professional football games, two basic models exist: (i) every club sells the broadcasting rights of his home games individually (sharing the revenues with the away team) or (ii) all the participants of a league, a cup or any other championship bundle the broadcasting rights of all the respective games and sell them jointly, for instance, through an assigned competent association formed by the clubs. Alternatively, the collective sale of media rights may be managed by the sports association governing the championship in question. Currently, the European-level football leagues (UEFA Champions League and UEFA Europa League) as well as virtually all major professional national football leagues in Europe practice a collective sale of broadcasting rights. Until the season 
2016/17, the premier-level football league of Spain, La Liga, represented a prominent exemption as broadcasting rights were sold individually by the teams.

A system of collective marketing of broadcasting rights is attractive for a league because it artificially creates a monopoly-like situation where the buyers, the broadcasting companies, face a single seller. In the case of premier-level football broadcasting rights, which enjoy a strong demand from football fans, the forced bundling results in supracompetitive media revenues (monopoly rent): while the media companies compete for the premium content, the teams of the league replace their interior competition for lucrative media deals by collective action (Cowie \& Williams, 1997). Instead, they usually auction the bundled broadcasting rights as an exclusive package like a win-maximizing monopolist. From an economics-point of view, the cooperation among the league participants to collectively sell the broadcasting rights constitutes a market-wide cartel ${ }^{2}$, where the competitors (the clubs) collude to extract rents from the other market side by increasing prices and limiting output. The welfare effects of this type of joint selling cartels have been subject to controversial analysis in the sports economic literature (inter alia, Atkinson, Stanley, \& Tschirhart, 1988; Késenne, 2000; 2009; 2014; Cave \& Crandall, 2001; Hoehn \& Lancefield, 2003; Falconieri, Palomino, \& Sákovics, 2004; Forrest, Simmons, \& Szymanski, 2004; Palasca, 2006; Gürtler, 2007; Massey, 2007; Noll, 2007; Peeters, 2011; 2012; Budzinski, 2019; Butler \& Massey, 2019).

On the one hand, it is expected to create considerable negative welfare effects. Due to the high importance of premier sports contents for broadcasting companies, their demand is relatively price-inelastic, leading to a dynamic bidding competition that drives up prices. Moreover, in order to further increase prices, the cartel experiences incentives to reduce the number or extent of available media rights. Furthermore, the cartel may hamper the development of certain innovative submarkets (e.g. new media markets or cross-border broadcasting), for instance, in order to protect rents from the exclusive sale to Pay-TV broadcasters. In doing so, it also causes negative dynamic welfare effects. Both increased prices and decreased

As long as the teams of the league form or (indirectly) control the governing body (i.e. the competent sports association like the UEFA in the case of European football), the participation of this governing body does not change the nature of the cartel (Budzinski \& Szymanski, 2015). 
quantities as well as decelerated innovation harm consumers as they are (one way or the other) passed-through media levels. For instance, if media companies must pay supracompetitive prices for football broadcasting rights, both football-loving consumers and consumers with other preferences are harmed. In the case of paid content like Pay-TV or streaming services as well as in the case of tax-/fee-based content like Public-TV, there is a direct harm through higher subscriptions prices or fees. In the case of advertised-financed free content there is an indirect negative effect as users/viewers will have to endure more advertising. Alternatively (or additionally), the broadcasting companies may decide to invest less money into other sports and non-sports programs, which harms all consumers who prefer other or, at the least, more contents than football broadcasting. Beyond these pass-through effects, bundling broadcasting rights into one monopolistic package may facilitate market foreclosure in media markets, i.e. harming competition on this market stage (Weeds, 2016). Altogether, these anticompetitive effects are widely agreed upon in the literature referenced above.

On the other hand, a collective sale of broadcasting rights may also come along with positive welfare effects. The most common one would be the competitive balance defense. It fundamentally relies on two assumptions: first, consumers value competitive balance, i.e. more competitive balance improves consumer welfare, and, second, centralized marketing leads to more competitive balance via a redistribution mechanism in the course of the allocation of the common revenues among the league participants. The first line of reasoning originally represents one of the cores of sports economics thinking (Rottenberg, 1956; Neale, 1964). However, empirical research always struggled to find convincing support (see for a comprehensive and recent literature review Pawlowski \& Nalbantis, 2019) and newer theory also casts doubt on the idea that more competitive balance is what sports consumers (dominantly) want (inter alia, Szymanski, 2001; Coates, Humphreys, \& Zhou, 2014; Humphreys \& Zhou, 2015; Budzinski \& Pawlowski, 2017; Pawlowski, Nalbantis, \& Coates, 2018). The second reasoning sensitively depends on the design of the actual redistribution mechanisms that a football league chooses to implement. This can improve financial balance among the competing teams but this is not an automatism (inter alia, Budzinski 2018; Budzinski \& Müller-Kock 2018). Al- 
together, the competitive balance defense used to be a popular reasoning in favor of centralized marketing but it has lost much of its appeal recently.

Another positive welfare effect of a centralized marketing system may be that the cartel creates a single point of sale providing efficiencies by a reduction of transaction costs for sellers and customers, i.e. media companies (Kienapfel \& Stein, 2007, pp. 11-12). While this reasoning cannot qualify per se as a defense for a marketwide cartel, it may become relevant given the specific nature of sports tournaments with knock-out character. In such cases, it may become difficult to sell the coverage of a whole championship in advance with a decentralized system, since nobody knows in advance who will survive the knock-out rounds and who will play against whom in later stages of the tournament. Thus, it would require selling the broadcasting rights stepwise in sequences corresponding to the knock-out rounds (Budzinski, 2012, pp. 59-60). In contrast to many of the national football leagues, the UEFA Champions League and the UEFA Europa League at least partly consist of knock-out elements. Selling the coverage of a whole season in a one-stop shopping, thus, requires a centralized sales system. Notwithstanding, the savings on transaction costs must be balanced with more efficient prices that are likely to result from stepwise auctions.

Eventually, a related line of reasoning refers to potential efficiency effects from creating a common brand of the championship, which may lead to increasing recognition and, by establishing a coherent league product, may increase the attractiveness for the consumers. The focus may be directed towards the championship as a whole instead of on individual games between teams, creating an additional consumption value for consumers (Kienapfel \& Stein, 2007, pp. 11-12), including additional services like the broadcasting of comprehensive highlights programs of match-days (European Commission, 2003, rec. 146) or championship-related merchandising. The crucial question here is whether a common brand and a common appearance could not be safeguarded without a collective sale of media rights as well, for instance, by a less-anticompetitive arrangement defining standards for the broadcasting (common design, etc.) that is sold individually. Furthermore, it appears to be doubtful whether a common brand and a common appearance justify 
considerably higher prices from a consumer welfare perspective, i.e. whether consumers really value brand and appearance that much.

In their decisions on joint selling arrangements by the UEFA for European competitions and by national league associations for national competitions, the European Commission $(2003,2005,2006)$ has expressed its assessment that the advantages of collective sales systems of broadcasting rights outweigh the disadvantages from a consumer welfare perspective. However, in accordance with article 101 (3) TFEU, collective sales arrangements are only exempted from the cartel prohibition if they satisfy a number of conditions (European Commission, 2003, 2005, 2006), which include the following, somewhat simplified list of the main remedies:

- Partial unbundling, i.e. limitation of the scope of exclusive vertical contracts: Centralized marketing must not consist of one comprehensive bundle sold in one auction to only one media company. Instead, the media rights must be unbundled into several separate packages in order to prevent market foreclosure. In particular, exclusive football live broadcasting rights must be separated in at least two balanced and meaningful packages, so that it becomes possible that more than one broadcasting service buys rights bundles (and a broadcasting monopoly is not the inevitable outcome). The bundles should be sold to different broadcasters (European Commission 2003, rec. 22)

- No single buyer obligation: In the case of already existing dominance of one broadcasting service in a given geographic market, the bundles must be sold to different broadcasting companies.

- Competitive tendering: Tenders must be invited by a non-discriminatory and transparent competitive bidding process in order to give all potential buyers an opportunity to compete for each of the rights packages.

- Sun-setting, i.e. limitation of the duration of exclusive vertical contracts: Exclusive contracts must include a 'sun-setting mechanism', i.e. the duration of contracts is limited and automatically and comprehensively ends after the duration period without any possibility to get prolonged. Instead, a fullblown new competitive tendering process must be set up after each period. 
According to current Commission practice in football the duration must not exceed a period of three seasons.

- Fall-back option, use obligation and parallel exploitation: In order to remedy output restrictions from the cartel arrangement, unused rights must fall back to the individual clubs for parallel, competitive exploitation. Moreover, in the case that a club's home match is not included in a live or near-live package, the club must earn the right to individually sell the live-broadcasting right to its home match.

- Trustee supervision of the tender procedure.

These conditions have been shaped in the course of three major case decisions by the European Commission, covering centralized marketing arrangements by the UEFA Champions League, the English Premier League and the German Bundesliga. Already in the first landmark case, the UEFA Champions League case (European Commission, 2003) most of the conditions for clearance were implemented including partial unbundling, competitive tendering, sun-setting, and the fall-back option. The second and third case, addressing centralized marketing of broadcasting rights of the German Bundesliga (European Commission, 2005) and the English Premier League (European Commission, 2006), revisited the conditions and obligations, specifying them (like the details of partial unbundling and competitive tendering) and adding the no single buyer obligation as well as the trustee supervision. In the Premier League-case, the European Commission (2006) considered the pay TV media channel British Sky Broadcasting ${ }^{3}$ to possess a dominant market position. Thus, Sky would have had the option to applying foreclosure strategies, if it had obtained comprehensive exclusive rights, i.e. if it had bought all the tendered bundles for live broadcasting. Therefore, the obligation of partial unbundling was extended by a further condition: no single buyer was allowed to purchase all of the major bundles. ${ }^{4}$ In the Bundesliga case, the Commission for the first time emphasized the participation of online-media channels in the auction (Evens, losifides, \& Smith, 2014), demanding earmarked packages for different media in order to pro-

Now Sky Ltd.

See Butler and Massey (2019) for an excellent ex post analysis of the effects of the Premier League case. 
tect and safeguard the possibility of dynamic competition for innovative media among broadcasters.

The decisions of the European Commission are (imperfectly) reflected in national antitrust decisions within the EU due to the close cooperation of national competition agencies with the European Commission within the European Competition Network (Budzinski \& Christiansen, 2005). For instance, the Bundeskartellamt (Federal Cartel Office of Germany) applied similar remedies to granting the centralized marketing of the national broadcasting rights of Germany's professional football leagues (Bundeskartellamt, 2008; 2012), including a no single buyer obligation, particularly with a view to the competition among traditional live broadcasting and online streaming (Bundeskartellamt, 2016; Monopolkommission, 2018).

In 2017, the main broadcasting rights (i.e. the rights to live-broadcasting) of the UEFA competitions (UEFA Champions League, UEFA Europa League, and UEFA Super Cup) were auctioned centralized by the UEFA in a three-year bundle (seasons 2018/2019 - 2020/21). In compliance with the Commission's obligations, the UEFA offered a variety of platform-neutral rights packages to buyers. Sky Sport (as a subsidiary of Sky Germany GmbH and, therefore, Sky Ltd.) acquired virtually all the rights to live-broadcast the UEFA Champions League in Germany. It broadcasts the games via its subscription-based Pay-TV service (that additionally includes the online streaming services Sky Go and Sky On Demand) as well as through its subscription-based online streaming service Sky Ticket. Presumably, in order to comply with the no single buyer desideratum, Sky sub-licensed some of these rights to DAZN. The latter, a subscription-based online service operated by Perform Group Ltd., acquired the majority of the live broadcasting rights of the UEFA Europa League. Furthermore, the live-broadcasting rights to selected games, albeit with considerable limitations (non-exclusive content, second choice), were sold to RTL Television for traditional advertising-financed free TV broadcasting. Germany is a quite representative example for an ongoing shift towards Pay-TV and paid-for online-only streaming services (inter alia, Sky Sport in Austria, Italy, and New Zealand, DAZN in Canada, Sky Pacific for the Pacific Islands, and O2 TV in Czech Republic). Furthermore, this trend is also observable on the national level; for instance, the live-broadcasting rights to the German Bundesliga went to the subscription- 
based offers of Sky and Eurosport and DAZN owns further exclusive livebroadcasting rights to games of the French Ligue 1, Italy's Serie A and Spain's La Liga.

\section{The Changing Landscape of Broadcasting Markets}

For many decades, two models of television (TV) dominated the market and, consequently, the discussion on broadcasting of sports: Free-TV versus Pay-TV. Free-TV concepts entail public service broadcasters, financed by taxpayer money, as well as commercial broadcasters financed by advertising revenues, whereas Pay-TV is usually subscription-based, either with a flatrate price or with a pay-per-view arrangement. However, the landscape of broadcasting markets is dynamically changing, on both the demand and the supply side.

The overall demand for online video content is increasing due to widespread access to broadband connections and the emergence of digital services. New technologies and the compatibility with mobile devices simplify usage and decrease the cost of online consumption. Although classic TV programs are still popular ${ }^{5}$, there is a steady shift from TV to online streaming and new media (Budzinski \& LindstädtDreusicke, 2019; Budzinski, Lindstädt-Dreusicke, \& Gaenssle, 2019). Especially younger generations prefer flexible ways of consumption, independent of time and place. On the one hand, non-linear (i.e. without strict programming schedule) video-on-demand (VoD) platforms allow time-independent access to content (like movies, serials, entertainment videos, etc.), on the other hand, online live streaming offers access to time-bound contents (like live-broadcasting) from various places using various devices (mobile smartphones and tablets, smart TVs, etc.). The daily usage of online videos in Germany, for instance, increased from 3 percent in 2007 to over 20 percent in 2016 and 2017 (Budzinski \& Lindstädt-Dreusicke, 2019: 10).

The shift from traditional TV to online streaming and new media can also be observed regarding sports consumption. There is an increasing demand of sports and e-sports content on platforms like YouTube and Twitch. This includes especially

According to the study by Frees and Koch (2018, p. 401) the daily average reach of TV is still 71.6 percent in Germany. 
novel disciplines, focusing on young (and often technophile) audiences, who generate their own championship pages or stream video content on social media pages, like e.g. HLTV (Counter-Strike) or CrossFit. ${ }^{6}$ Notwithstanding, this development can also be observed for more traditional sports (like football). As a recent study reports, sports contents do not only drive TV consumption but also consumption of online streaming services (Budzinski, Lindstädt-Dreusicke, \& Gaenssle, 2019). All age groups, but especially young sports fans, use online options (see figure 1). This indicates that the overall trend will intensify over time.

Figure 1 Sports Consumption - Streaming vs. TV [percent]

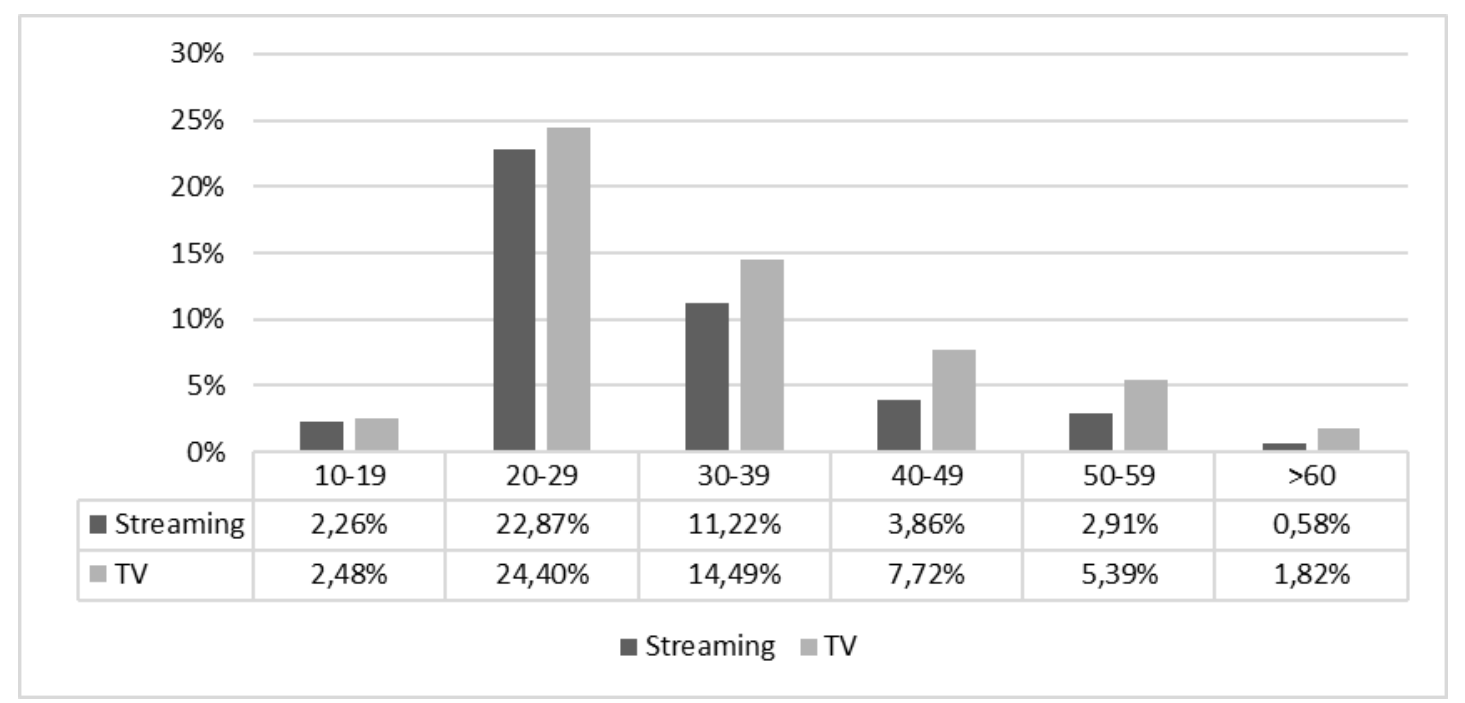

Source: Budzinski, Lindstädt-Dreusicke, \& Gaenssle (2019) ${ }^{7}$

The market of online streaming services is heterogeneous and dynamic, characterized by intensive competition and considerable new entry dynamics during the last decade (Budzinski \& Lindstädt-Dreusicke, 2019). It currently consists of considerably different business models, including for instance (usually subscription-based) paidfor streaming (inter alia, Sky and Netflix), advertising-financed streaming without charging the consumers (inter alia, YouTube and Twitch) as well as online libraries from public service broadcasters and other traditional TV channels. In many countries, including most EU member states, comparatively young online-only competitors like Netflix and Amazon (with its Prime service) are the current market leaders

6 See: https://www.hltv.org/ for Counter Strike or https://games.crossfit.com/sanctionals for CrossFit.

7 Questioned: 2,931 in Germany, average age: 31.56 years. 
in online streaming. However, incumbent media players, who were well-positioned in the offline media markets, try to recover lost ground by setting up their own streaming services, e.g. Disney+, Sky Ticket, or Joyn, and/or forming powerful alliances, e.g. the recent Disney-Fox and AT\&T-Time Warner mega-mergers (Stöhr et al., 2019). In this dynamic competition, premium sports contents represent an important tool to attract viewers and generate subscriptions. Thus, various platforms offer sports contents such as live broadcasting/streams, reporting and media coverage or documentaries. Figure 2 exemplarily shows the usage of online streaming services sorted by service suppliers in Germany in 2018. At the time of the survey, 34.5 percent of respondents said they were using online video platforms. Notably, with its specialization on sports contents, newcomer DAZN (since 2016) already reached 2.8 percent. However, due to the economic characteristics of the market for online streaming services (like platform effects and data-driven business models; Budzinski \& Stöhr, 2018; Budzinski \& Lindstädt-Dreusicke, 2019), it must be expected that, in the longer run, only few services will accumulated considerable market shares and many of the current and upcoming services will leave the market.

Figure 1 VoD-Platforms and Usage 2018 in Germany [percent]

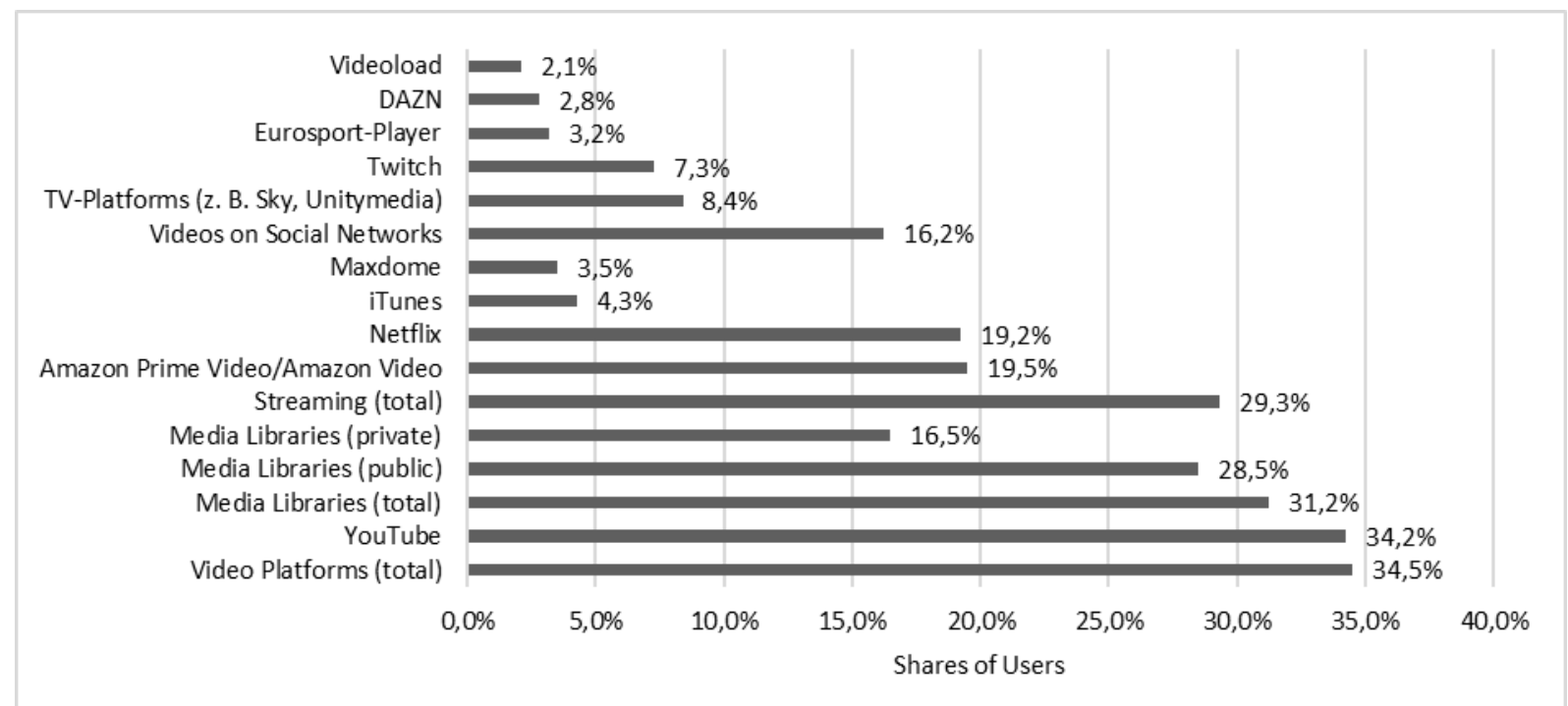

Source: Die Medienanstalten (2018, p. 49). ${ }^{8}$

8 Base: 70,094 million people over the age of 14 in Germany; Questioned: 29,379 million people over the age of 14 in Germany, online streaming usage more than once a month. 
Already now, a large share of UEFA content is only available through subscriptionbased online streaming services and this development is set to continue and further escalate. However, watching football broadcasting online significantly differs from watching on traditional TV: instead of just switching between TV channels on the remote control, fans need to subscribe to different services, which may run on different player systems and require different access technologies. Thus, developments previously observable in markets with dominance of Pay-TV over Free-TV (like in the case of the English Premier League; Butler \& Massey 2019) are further aggravated and extended by the shift towards online broadcasting. This raises the question whether consumer welfare is still safeguarded by the 'old' remedies, i.e. conditions and obligations made with traditional TV in mind.

\section{Welfare Effects in New Media Markets}

As argued in section 2, centralized marketing comes with negative welfare effects for consumers and the conditions and obligations are meant to remedy these effects. It may already be controversial whether they have achieved this goal in the offline media world and, furthermore, some of the obligations are likely to be displaying increasing negative consumer welfare in online media markets. Crucially, the core conditions and obligations seeking to safeguard competition and consumer welfare, the partial unbundling as well as the no single buyer obligation, appear to be particularly problematic here.

The underlying idea of partial unbundling and no single buyer is to avoid a monopoly football broadcaster ${ }^{9}$ and promote competition among football broadcasters - thus, to lower prices for consumers. While this may work for competition amongst Free-TV and for competition among Free- and Pay-TV alternatives, the price-decreasing effect is empirically not supported for Pay-TV competition in England. Instead, the overall price as well as the price per game is higher with competing broadcasters than under a monopoly (Butler \& Massey, 2019). Reasons may include incentives to overbidding: a viable market position in the downstream

9 From an antitrust economics point of view, this term may be imprecise since it is not completely clear (despite their premium content character for media) whether football live-broadcasts represent a single relevant market. 
broadcasting market can only obtained with premium content and football livebroadcasting rights belong to the scarce quantity of such rights, therefore, broadcasters enjoy incentives to overbid to secure a specific portfolio (Hoehn \& Lancefield, 2003). Another reason may be that the different bundles offered by UEFA are not substitutes but rather complements for football fans. Consequently, each media company that has secured live-broadcasting rights may experience incentives to treat consumers as a monopolist because it offers part of something that consumers want as a whole. These incentives will be particularly strong if only few media companies bought live-broadcasting rights. Alternatively, another reason may be market division if consumers segment themselves (for instance, into casual and hardcore fans) and the bundles offered in the auctions resemble this segmentation (e.g. two bundles: a basic package and an extended package). As a consequence, each broadcaster may be able to treat 'his' consumer segment as if he was a monopolist (Butler \& Massey, 2019). Negative impacts on consumer welfare may even increase, if the strong duopolists decide to strategically split contents, forcing consumers to subscribe to both services. Again, this effect rests on a narrow market structure.

These incentives for duopolists to strategically raise prices are even stronger for online streaming services than for Pay-TV. Online streaming services compete for subscribers in a very dynamic market with a considerable number of competitors that is prone to significantly narrow down in the future (see section 3). Therefore, premium content is of paramount importance to gain subscribers and grow as a streaming service - and, eventually, to belong to the survivors in the market. Furthermore, lock-in effects of consumers to streaming services are likely to be at the least as relevant as with Pay-TV. Thus, the scope for the strategic setting of supracompetitive prices may be considerable in the new media world.

However, even if no strategic considerations played a role, it would still be questionable whether two competing subscription-based broadcasting services would provide a lower-price offer to consumers than one monopoly broadcaster. If the number of live-broadcasts is constant (use obligation), the price of two subscriptions to competing streaming services will likely exceed the subscription price of a monopoly supplier simply due to the individual cost structure. If that is the case, 
then the remedies partial unbundling and no single buyer, leading to a narrow oligopoly offering live-broadcasting of football, ceteris paribus (further) decrease consumer welfare in the sense that they lead to a accumulated price to consume the same amount of UEFA football.

The obligations to partially unbundle live-broadcasting rights and to sell them to at least two different broadcasters cause an additional effect for consumers: it eliminates a one-stop-shopping option. One-stop-shopping implies the option for football fans to consume all live-broadcasting from one source, i.e. one single broadcasting or streaming service. One-stop shopping is attractive to consumers if the (transaction) costs of using more than one supplier are significant. Again, this is an issue that is rather unproblematic if broadcasting rights are split among Free-TV channels: one press on the remote control switches the consumer to the desired channel and information about all channels is easily available by the TV program guide (be it a printed magazine in former times or digital). Already if Pay-TV comes into play, transaction costs for the consumers increase since subscription and payment arrangements must be made with the different broadcasters. This is especially true if the rights bundles are allocated among different Pay-TV broadcasters only. An allocation to paid-for, subscription-based online streaming services further increases transaction costs for consumers as they need to handle multiple subscriptions (contracts, payments, passwords, etc.), which may require different players and software packages and, thus, to learn how to use the different systems. Furthermore, a common program guide is missing. In a survey conducted among 102 users of online football streaming services in Germany, 80.6 per cent are annoyed by increasing information costs to find out which game is broadcasted when by what streaming service. ${ }^{10}$ The survey is non-representative with a bias towards younger and higher educated consumers, which implies that representative numbers may even be higher.

That online services increase search and information costs appears to be surprising at first sight since online streaming services contain the possibility of data-based individualized search and recommendation services. These are usually hailed as an

10 Weber (2019, p. 83). Furthermore, 68.5 per cent find the sublicensing of Sky rights to DAZN "confusing". 
important success factor of online services (inter alia, Budzinski \& Stöhr, 2018). However with the segmentation of broadcasting rights demanded by the obligations of partial unbundling and no single buyer, the positive consumer welfare effects of these are limited because, generally speaking, there is no cross-platform/service information. On each streaming platform, consumers cannot search for offerings of other (competitive) suppliers and do not receive recommendations to streams of competing services. Thus, the fragmentation of the broadcasting rights also considerably limits possible consumer advantages of such individualized search and recommendation services.

Altogether, the partial unbundling and the no single buyer obligation harm consumers of online media in two ways: they increase prices and transaction costs. With respect to the other remedies, Butler and Massey (2019) conclude that, at present, the fall back option has very minor relevance because nearly all games are included in live or near-live packages - and the movement towards online streaming services is likely to continue this trend. Furthermore, competitive tendering, sun-setting, and trustee supervision all appear to be and remain supportive to consumer welfare.

\section{Antitrust Implications}

The discussion in the preceding section has revealed that parts of the antitrust remedies imposed by the European Commission, namely partial unbundling and no single buyer rule, harm consumers by increasing prices and transaction costs. Notwithstanding this result, it would be wrong, though, to conclude that 'just' giving up these obligations would be the logical consequence. It needs to be remembered that these obligations are mandated by competition authorities in order to remedy negative consumer welfare effects from the collective sale of broadcasting rights, in particular from the monopoly pricing of the football league/association, passedthrough to consumers in various ways (see section 2). If the introduction of artificial competition elements into centralized marketing through the obligations of partial unbundling and no single buyer does effectively not remedy negative consumer welfare effects in the online age anymore, but instead aggravates them, 
then the justification for exempting the broadcasting rights cartel from the cartel prohibition becomes obsolete.

An individual sale of broadcasting rights by the participating clubs would effectively prevent the anticompetitive effects created by centralized marketing and although it would likely also cause the burden of multiple subscriptions for consumers, it would certainly drive prices down. This points to an inherent trade-off: more and smaller bundles are likely to reduce subscription prices, however, at the same time, they are increasing the transaction costs for multiple subscriptions. This tradeoff may be viewed as a reason to think about more adequate remedies for a collective sale system of broadcasting rights instead of calling for its abandonment. It also emphasizes, however, that increasing the number of bundles in a collective sale system by means of obligations may partly alleviate one problem (high prices) but aggravate the other one (high transaction costs due to multiple subscriptions). Along similar lines, Butler and Massey (2019) suggest with a view to the Pay-TV market in England to establish a maximum of 50 per cent (or even lower thresholds) of broadcasting rights/bundles that one single buyer may acquire. Again, while this may fuel competition on the media market, it also boosts multiple subscriptions.

Next to detailing the number of bundles and the amount that a single buyer may acquire, the content of the bundles may be regulated, e.g. by mandating clubspecific bundles. While club fans desire to watch all games of their favorite club, competition fans love to follow the overall tournament (Szymanski, 2001; Peeters, 2012). For club fans, club-specific bundles would indeed solve the trade-off, whereas, however, competition fans still would face multiple subscriptions. Moreover, this idea attempts to closely mirror individual marketing by the clubs, so it would be preferable to ban centralized marketing altogether. Another avenue would target to regulate the type of the buyer, like, for instance, a condition to sell a minimum number of rights bundles to Free-TV or to free streaming services (advertising-financed and/or data-based) and/or to oblige paid-for services to grant a minimum number of non-exclusive rights to free services.

However, an effective remedy to the anticompetitive effects of a collective sale of football broadcasting rights requires addressing one of the causes for (i) high prices 
on the upstream level (the rights auction), (ii) additional mark-ups on the downstream level (subscription prices), and (iii) consumers facing multiple subscriptions issues. If competition authorities like the European Commission prohibited or limited the exclusivity of live-streaming rights, then all three issues would be alleviated (for (i) and (ii) also: Butler \& Massey, 2019). No (or less) exclusivity anymore would definitely drive down prices on both levels: the willingness-to-pay from media companies including paid-for online streaming services would decrease as would their ability to lock-in or segment consumers. Broadcasting/streaming rights would gain the character of substitutes (instead of being complements), which would intensify competition for viewers (fans). Furthermore, one-stop shopping offers may become available for consumers without the downside of monopoly prices and lock-in effects. Add to this that exclusivity virtually does nothing for consumer welfare, so that a loss of exclusivity would not negatively affect consumers. Also, the efficiency defenses stipulated by the European Commission - the single point of sale and the common brand and appearance - would not be harmed as well.

A variant of restricting exclusivity refers to geographic territory exclusivity, i.e. the sale of rights exclusive for (and restricted to) broadcasting in one specific country. The current conditions and obligations for exempting collective sale systems of broadcasting rights in the EU allow for this type of exclusivity and prohibit any commercial circumvention like showing a Greek broadcasting of English premierleague football in a pub in the United Kingdom (the so-called Murphy-case; Butler \& Massey, 2019). However, streaming markets are considerably less bound to national borders than traditional TV markets. Therefore, allowing consumers (by means of conditions and obligations) to freely choose between different countries' streams (distinguishing themselves by commentator's language and focus of the broadcast on their local heroes) may already contribute considerably to consumer welfare. Banning restrictions on geographic territory altogether represents another option.

Eventually, effective restrictions to the exclusivity of the bundles' content could be combined with an obligation to create a common program guide or to grant access to the relevant information for third-parties offering such a service. Irrespective of the availability of a one-stop-shopping option, such a condition for approval would 
considerably reduce the burden of multiple subscriptions. Alternatively, streaming services could be mandated to display cross-service search and recommendation results. However, such an obligation would probably be difficult to police and represents a comparatively strong intervention into the respective business models of the streaming services.

\section{References}

Atkinson S., Stanley, L. \& Tschirhart, J. (1988). Revenue sharing as an incentive in an agency problem: An example from the National Football League. RAND Journal of Economics, 19(1), 27-43.

Budzinski, O. (2012). The institutional framework for doing Sports Business: Principles of EU Competition Policy in Sports Markets. International Journal of Sport Management and Marketing, 11(1-2), 44-72.

Budzinski, O. (2018). Financial regulation as an anticompetitive institution. In M. Breuer \& D. Forrest (Eds.), The Palgrave Handbook on the Economics of Manipulation in Professional Sports (pp. 159-179). Basingstoke: Palgrave.

Budzinski, O. (2019). Competition policy in sports markets. In P. Downward et al. (Eds.), Handbook of Sports Economics. Los Angeles: Sage 2019, forthcoming.

Budzinski, O. \& Christiansen, A. (2005). Competence allocation in EU competition policy as an interest-driven process. Journal of Public Policy, 25(3), 313-337.

Budzinski, O. \& Lindstädt-Dreusicke, N. (2019). The new media economics of videoon-demand markets: lessons for competition policy. IImenau Economics Discussion Papers 25 (125).

Budzinski, O., Lindstädt-Dreusicke, N., \& Gaenssle, S. (2019). YouTube vs. Netflix: An empirical analysis of consumer behavior and competition in audiovisual markets. EMMA Conference Paper, Limassol, Cyprus.

Budzinski, O., \& Müller-Kock, A. (2018). Is the revenue allocation scheme of Formula One motor racing a case for European competition policy? Contemporary Economic Policy, 36(1), 215-233.

Budzinski, O., \& Pawlowski, T. (2017). The behavioural economics of competitive balance - Theories, findings and implications. International Journal of Sport Finance, 12(2), 109-122. 
Budzinski, O., \& Stöhr, A. (2018). Competition policy reform in Europe and Germany - Institutional change in the light of digitization. European Competition Journal, 15(1), doi 10.1080/17441056.2018.1555942.

Budzinski, O., \& Szymanski, S. (2015). Are restrictions of competition by sports associations horizontal or vertical in nature? Journal of Competition Law \& Economics, 11(2), 409-429.

Bundeskartellamt (2008). Zentralvermarktung: DFL muss bei Verbraucherbeteiligung nachbessern.

https://www.bundeskartellamt.de/SharedDocs/Meldung/DE/Pressemitteilungen/2 008/17_07_2008_DFL-Zentralvermarktung.html.

Bundeskartellamt (2012). Fallbericht: Zentrale Vermarktung der Medienrechte der Fußball Bundesliga und der 2. Bundesliga ab der Saison 2013/2014. Beschluss B6-114/10 vom 12.01.2012, Bonn.

Bundeskartellamt (2016). Vermarktung der medialen Verwertungsrechte an Fußballspielen der Bundesliga und der 2. Bundesliga ab der Saison 2017/2018. Beschluss B6-32/15 vom 11.04.216, Bonn.

Butler, R., \& Massey, P. (2019). Has competition in the market for subscription sports broadcasting benefited consumers? The case of the English Premier League. Journal of Sports Economics, 20(4), 603-624.

Cave, M., \& Crandall, R. (2001). Sports rights and the broadcast industry. Economic Journal, 111, F4-F26.

Coates, D., Humphreys, B. R., \& Zhou, L. (2014). Reference-dependent preferences, loss aversion, and live game attendance. Economic Inquiry, 52(3), 959-973.

Cowie, C., \& Williams, M. (1997). The economics of sports rights. Telecommunications Policy, 21(7), 619-634.

Die Medienanstalten (2018). Digitalisierungsbericht Video: Digitalisierung vollendet - Wie linear bleibt das Fernsehen? die medienanstalten - ALM GbR, 1-71.

Evens, T., losifides, P., \& Smith, P. (2014). Regulierung von Sportrechten im Fernsehen. Media Perspektiven, 2014(2), 100-110.

European Commission (2003). COMP/C.2-37.398 - Joint selling of the commercial rights of the UEFA Champions League. Commission Decision, 2003/778/EC, Brussels. 
European Commission (2005). Case COMP/C-2/37.214 - Joint selling of the media rights to the German Bundesliga. Commission Decision, $C(2005) 78$, Brussels.

European Commission (2006). COMP/C-2/38.173 - Joint selling of the media rights to the FA Premier League. Commission Decision, C(2006)/868, Brussels.

Falconieri, S., Palomino, F., \& Sákovics, J. (2004). Collective versus individual sale of television rights in league sports. Journal of the European Economic Association, $2(5), 833-862$.

Forrest, D., Simmons, R., \& Szymanski, S. (2004). Broadcasting, attendance and the inefficiency of cartels. Review of Industrial Organization, 24(2), 243-265.

Frees, B. \& Koch, W. (2018). ARD/ZDF-Onlinestudie 2018: Zuwachs bei medialer Internetnutzung und Kommunikation - Ergebnisse aus der Studienreihe „Medien und ihr Publikum" (MiP). Media Perspektiven, 2018(2), 398-413.

Gürtler, O. (2007). A rationale for the coexistence of central and decentral marketing in team sports. German Economic Review, 8(1), 89-106.

Hoehn, T., \& Lancefield, D. (2003). Broadcasting and sport. Oxford Review of Economic Policy, 19, 552-568.

Humphreys, B. R., \& Zhou, L. (2015). The Louis-Schmelling paradox and the league standing effect reconsidered. Journal of Sports Economics, 16(8), 835-852.

Késenne, S. (2000). Revenue sharing and competitive balance in professional team sports. Journal of Sports Economics, 1(1), 56-65.

Késenne, S. (2009). The impact of pooling and sharing of broadcasting rights in professional team sports. International Journal of Sport Finance, 4(3), 211-218.

Késenne, S. (2014). The collection and distribution of media rights in a winmaximization league. In J. Goddard \& P. Sloane (Eds.), Handbook on the economics of professional football (pp. 73-79). Cheltenham: Elgar.

Kienapfel, P., \& Stein, A. (2007). The application of articles 81 and 82 EC in the sport sector. Competition Policy Newsletter, 3, 6-14.

Massey, P. (2007). Are sports cartels different? An analysis of EU Commission decisions concerning collective selling agreements for football broadcasting rights. World Competition, 30, 87-106.

Monopolkommission (2018). Wettbewerb 2018, 22. Hauptgutachten. Bonn. 
Neale, W. C. (1964). The peculiar economics of professional sports: A contribution to the theory of the firm in sporting competition and in market competition. Quarterly Journal of Economics, 78(1), 1-14.

Noll, R. G. (2007). Broadcasting and team sports. Scottish Journal of Political Economy, 54(3), 400-421.

Palasca, S. (2006). Collective selling of broadcasting rights in team sports. In W. Andreff \& S. Szymanski (Eds.), Handbook on the economics of sport (pp. 719729). Cheltenham: Elgar.

Pawlowski, T., Nalbantis, G., \& Coates, D. (2018). Perceived game uncertainty, suspense and the demand for sport. Economic Inquiry, 56(1), 173-192.

Pawlowski, T., \& Nalbantis, G. (2019). Competitive balance: Measurement and relevance. In P. Downward et al. (Eds.), Handbook of Sports Economics. Los Angeles: Sage, forthcoming.

Peeters, T. (2011). Broadcasting rights and competitive balance in European soccer. International Journal of Sport Finance, 6(1), 23-39.

Peeters, T. (2012). Media revenue sharing as a coordination device in sports leagues. International Journal of Industrial Organization, 30(2), 153-163.

Rottenberg, S. (1956). The baseball player's labour market. Journal of Political Economy, 64(3), 242-258.

Stöhr, A., Noskova, V., Kunz-Kaltenhäuser, P., Gaenssle, S., \& Budzinski, O. (2019). Happily ever after? - Vertical and horizontal mergers in the U.S. media industry. Ilmenau Economics Discussion Papers 25 (126).

Szymanski, S (2001). Income inequality, competitive balance and the attractiveness of team sports. The Economic Journal, 111, 69-84.

Weber, C. (2019). Europäischer Fußball on Demand - Zur Zukunft der Zentralvermarktung im digitalen Zeitalter. Master Thesis, Ilmenau University of Technology. Weeds, H. (2016). TV wars: Exclusive content and platform competition in pay TV. The Economic Journal, 126(594), 1600-1633. 


\title{
Diskussionspapiere aus dem Institut für Volkswirtschaftslehre
}

\author{
der Technischen Universität IImenau
}

Nr. 69 Budzinski, Oliver: Empirische Ex-Post Evaluation von wettbewerbspolitischen Entscheidungen: Methodische Anmerkungen, Januar 2012.

Nr. 70 Budzinski, Oliver: The Institutional Framework for Doing Sports Business: Principles of EU Competition Policy in Sports Markets, January 2012.

Nr. 71 Budzinski, Oliver; Monostori, Katalin: Intellectual Property Rights and the WTO, April 2012.

Nr. 72 Budzinski, Oliver: International Antitrust Institutions, Juli 2012.

Nr. 73 Lindstädt, Nadine; Budzinski, Oliver: Newspaper vs. Online Advertising Is There a Niche for Newspapers in Modern Advertising Markets?

Nr. 74 Budzinski, Oliver; Lindstädt, Nadine: Newspaper and Internet Display Advertising - Co-Existence or Substitution?, Juli 2012b.

Nr. 75 Budzinski, Oliver: Impact Evaluation of Merger Control Decisions, August 2012.

Nr. 76 Budzinski, Oliver; Kuchinke, Björn A.: Deal or No Deal? Consensual Arrangements as an Instrument of European Competition Policy, August 2012.

Nr. 77 Pawlowski, Tim, Budzinski, Oliver: The (Monetary) Value of Competitive Balance for Sport Consumers, Oktober 2012.

Nr. 78 Budzinski, Oliver: Würde eine unabhängige europäische Wettbewerbsbehörde eine bessere Wettbewerbspolitik machen?, November 2012.

Nr. 79 Budzinski, Oliver; Monostori, Katalin; Pannicke, Julia: Der Schutz geistiger Eigentumsrechte in der Welthandelsorganisation - Urheberrechte im TRIPS Abkommen und die digitale Herausforderung, November 2012.

Nr. 80 Beigi, Maryam H. A.; Budzinski, Oliver: On the Use of Event Studies to Evaluate Economic Policy Decisions: A Note of Caution, Dezember 2012.

Nr. 81 Budzinski, Oliver; Beigi, Maryam H. A.: Competition Policy Agendas for Industrializing Countries, Mai 2013.

Nr. 82 Budzinski, Oliver; Müller, Anika: Finanzregulierung und internationale Wettbewerbsfähigkeit: der Fall Deutsche Bundesliga, Mai 2013. 
Nr. 83 Doose, Anna Maria: Methods for Calculating Cartel Damages: A Survey, Dezember 2013.

Nr. 84 Pawlowski, Tim; Budzinski, Oliver: Competitive Balance and Attention Level Effects: Theore-tical Considerations and Preliminary Evidence, März 2014.

Nr. 85 Budzinski, Oliver: The Competition Economics of Financial Fair Play, März 2014.

Nr. 86 Budzinski, Oliver; Szymanski, Stefan: Are Restrictions of Competition by Sports Associations Horizontal or Vertical in Nature?, März, 2014.

Nr. 87 Budzinski, Oliver: Lead Jurisdiction Concepts Towards Rationalizing Multiple Competition Policy Enforcement Procedures, Juni 2014.

Nr. 88 Budzinski, Oliver: Bemerkungen zur ökonomischen Analyse von Sicherheit, August 2014.

Nr. 89 Budzinski, Oliver; Pawlowski, Tim: The Behavioural Economics of Competitive Balance: Implications for League Policy and Championship Management, September 2014.

Nr. 90 Grebel, Thomas; Stuetzer, Michael: Assessment of the Environmental Performance of European Countries over Time: Addressing the Role of Carbon, September 2014.

Nr. 91 Emam, Sherief; Grebel, Thomas: Rising Energy Prices and Advances in Renewable Energy Technologies, July 2014.

Nr. 92 Budzinski, Oliver; Pannicke, Julia: Culturally-Biased Voting in the Eurovision Song Contest: Do National Contests Differ?, December 2014.

Nr. 93 Budzinski, Oliver; Eckert, Sandra: Wettbewerb und Regulierung, März 2015.

Nr. 94 Budzinski, Oliver; Feddersen, Arne: Grundlagen der Sportnachfrage: Theorie und Empirie der Einflussfaktoren auf die Zuschauernachfrage, Mai 2015.

Nr. 95 Pannicke, Julia: Abstimmungsverhalten im Bundesvision Song Contest: Regionale Nähe versus Qualität der Musik, Oktober 2015.

Nr. 96 Budzinski, Oliver; Kretschmer, Jürgen-Peter: Unprofitable Horizontal Mergers, External Effects, and Welfare, October 2015.

Nr. 97 Budzinski, Oliver; Köhler, Karoline Henrike: Is Amazon The Next Google?, October 2015. 
Nr. 98 Kaimann, Daniel; Pannicke, Julia: Movie success in a genre specific contest: Evidence from the US film industry, December 2015.

Nr. 99 Pannicke, Julia: Media Bias in Women's Magazines: Do Advertisements Influence Editorial Content?, December 2015.

Nr. 100 Neute, Nadine; Budzinski, Oliver: Ökonomische Anmerkungen zur aktuellen Netzneutralitätspolitik in den USA, Mai 2016.

Nr. 101 Budzinski, Oliver; Pannicke, Julia: Do Preferences for Pop Music Converge across Countries? - Empirical Evidence from the Eurovision Song Contest, Juni 2016.

Nr. 102 Budzinski, Oliver; Müller-Kock, Anika: Market Power and Media Revenue Allocation in Professonal Sports: The Case of Formula One, Juni 2016.

Nr. 103 Budzinski, Oliver: Aktuelle Herausforderungen der Wettbewerbspolitik durch Marktplätze im Internet, September 2016.

Nr. 104 Budzinski, Oliver: Sind Wettbewerbe im Profisport Rattenrennen?, Februar 2017.

Nr. 105 Budzinski, Oliver; Schneider, Sonja: Smart Fitness: Ökonomische Effekte einer Digitalisierung der Selbstvermessung, März 2017.

Nr. 106 Budzinski, Oliver; Pannicke, Julia: Does Popularity Matter in a TV Song Competition? Evidence from a National Music Contest, April 2017.

Nr. 107 Budzinski, Oliver; Grusevaja, Marina: Die Medienökonomik personalisierter Daten und der Facebook-Fall, April 2017.

Nr. 108 Budzinski, Oliver: Wettbewerbsregeln für das Digitale Zeialter - Die Ökonomik personalisierter Daten, Verbraucherschutz und die 9.GWB-Novelle, August 2017.

Nr. 109 Budzinski, Oliver: Four Cases in Sports Competition Policy: Baseball, Judo, Football, and Motor Racing, September 2017.

Nr. 110 Budzinski, Oliver: Market-internal Financial Regulation in Sports as an Anticompetitive Institution, October 2017.

Nr. 111 Bougette, Patrice; Budzinski, Oliver; Marty, Frédéric: EXPLOITATIVE ABUSE AND ABUSE OF ECONOMIC DEPENDENCE: WHAT CAN WE LEARN FROM THE INDUSTRIAL ORGANIZATION APPROACH?, December 2017.

Nr. 112 Budzinski, Oliver; Gaenssle, Sophia: The Economics of Social Media Stars: An Empirical Investigation of Stardom, Popularity, and Success on YouTube, Januar 2018. 
Nr. 113 Gaenssle, Sophia; Budzinski, Oliver; Astakhova Daria: Conquering the Box Office: Factors, influencing Success of International Movies in Russia, Mai 2018.

Nr. 114 Budzinski, Oliver; Stöhr, Annika: Die Ministererlaubnis als Element der deutschen Wettbewerbsordnung: eine theoretische und empirische Analyse, Juli 2018.

Nr. 115 Budzinski, Oliver; Kuchinke, Björn A.: Modern Industrial Organization Theory of Media Markets and Competition Policy Implications, September 2018.

Nr. 116 Budzinski, Oliver; Lindstädt-Dreusicke, Nadine: The New Media Economics of Video-on-Demand Markets: Lessons for Competition Policy, Oktober 2018.

Nr. 117 Budzinski, Oliver; Stöhr, Annika: Competition Policy Reform in Europe and Germany - Institutional Change in the Light of Digitization, November 2018.

Nr. 118 Budzinski, Oliver; Noskova, Victoriia; Zhang, Xijie: The Brave New World of Digital Personal Assistants: Benefits and Challenges from an Economic Perspective, December 2018.

Nr. 119 Bougette, Patrice; Budzinski, Oliver \& Marty, Frédéric: EXPLOITATIVE ABUSE AND ABUSE OF ECONOMIC DEPENDENCE: WHAT CAN WE LEARN FROM AN INDUSTRIAL ORGANIZATION APPROACH? [Updated Version 2018], December 2018.

Nr. 120 Bartelt, Nadja: Bundling in Internetmärkten - Ökonomische Besonderheiten, Wettbewerbseffekte und Regulierungsimplikationen, Dezember 2018.

Nr. 121 Budzinski, Oliver; Feddersen, Arne: Measuring Competitive Balance in Formula One Racing, März 2019.

Nr. 122 Budzinski, Oliver; Kohlschreiber, Marie; Kuchinke, Björn A. \& Pannicke, Julia: Does Music Quality Matter for Audience Voters in a Music Contest, März 2019.

Nr. 123 Gaenssle, Sophia; Budzinski, Oliver: Stars in Social Media: New Light Through Old Windows?, April 2019.

Nr. 124 Stöhr, Annika; Budzinski, Oliver: Ex-post Analyse der MinistererlaubnisFälle - Geminwohl durch Wettbewerbsbeschränkungen?, April 2019. 
Nr. 125 Budzinski, Oliver; Lindstädt-Dreusicke, Nadine: The New Media Economics of Video-on-Demand Markets: Lessons for Competition Policy (Updated Version), May 2019.

Nr. 126 Stöhr, Annika; Noskova, Victoriia; Kunz-Kaltenhäuser, Philipp; Gaenssle, Sophia \& Budzinski, Oliver: Happily Ever After? - Vertical and Horizontal Mergers in the U.S. Media Industry, June 2019.

Nr. 127 Budzinski, Oliver; Stöhr, Annika: Der Ministererlaubnis-Fall Miba/Zollern: Europäische Champions statt Wettbewerb?, Juni 2019. 